AperTO - Archivio Istituzionale Open Access dell'Università di Torino

\title{
Fungal biodiversity and in situ conservation in Italy
}

\section{This is the author's manuscript}

Original Citation:

Availability:

This version is available http://hdl.handle.net/2318/123069

since 2016-10-06T17:16:24Z

Published version:

DOI:10.1080/11263504.2011.633115

Terms of use:

Open Access

Anyone can freely access the full text of works made available as "Open Access". Works made available under a Creative Commons license can be used according to the terms and conditions of said license. Use of all other works requires consent of the right holder (author or publisher) if not exempted from copyright protection by the applicable law. 
This is the author's final version of the contribution published as:

G. Venturella; E. Altobelli; A. Bernicchia; S. Di Piazza; D. Donnini; M.L. Gargano; S.P. Gorjòn; V.M. Granito; A. Lantieri; D. Lunghini; A.

Montemartini; F. Padovan; M. Pavarino; L. Pecoraro; C. Perini; G. Rana; C. Ripa; E. Salerni; E. Savino; P.E. Tomei; A. Vizzini; A. Zambonelli; M. Zotti. Fungal biodiversity and in situ conservation in Italy. PLANT BIOSYSTEMS. 145(4) pp: 950-957.

DOI: $10.1080 / 11263504.2011 .633115$

The publisher's version is available at:

http://www.tandfonline.com/doi/abs/10.1080/11263504.2011.633115

When citing, please refer to the published version.

Link to this full text:

http://hdl.handle.net/2318/123069 


\section{Fungal biodiversity and in situ conservation in Italy}

G. Venturella , E. Altobelli, A. Bernicchia, S. Di Piazza, D. Donnini , M. L. Gargano , S. P. Gorjòn , V. M. Granito, A. Lantieri , D. Lunghini , A. Montemartini , F. Padovan , M. Pavarino , L. Pecoraro , C. Perini , G. Rana , C. Ripa , E. Salerni , E. Savino , P. E. Tomei , A. Vizzini , A. Zambonelli \& M. Zotti

\section{Abstract}

A remarkable increase in knowledge of fungal biodiversity in Italy has occurred in the last five years. The authors report up-to-date numbers of fungi (Basidiomycota and Ascomycota) by regions together with distributional and ecological data on hypogeous fungi. Specific case studies such as alpine fungi, orchid mycorrhizas symbionts, invasive species, and the use of macrofungi as food by red squirrels are analyzed. In situ conservation strategies carried out on target species and/or taxonomic groups are also indicated.

Keywords: Ascomycota, Basidiomycota, biodiversity, Italy, mycology,

\section{Introduction}

A year before the Earth Summit in Rio de Janeiro (Brazil), the Italian Botanical Society's Working Group for Mycology drafted a document containing two priority targets: increased mycological research and evaluation of fungal diversity in Italy with particular reference to larger fungi. As a result, regional checklists were published for Campania, Liguria, Sicily, and Tuscany, and these collectively contribute to the checklist of Italian fungi (Basidiomycetes) (Onofri et al. 2005 Onofri, S, Bernicchia, A, Filipello Marchisio, V, Padovan, FPerini, C. 2005. Checklist dei funghi italiani - Checklist of Italian fungi, Basidiomycetes, 1-380. Sassari: C. Delfino ed.. ). After that, a descriptive and iconographic review dealing of Italian Basidiomycota was released by Boccardo et al. (2008 Boccardo, F, Traverso, M, Vizzini, A and Zotti, M. 2008. Funghi d'Italia, 623Bologna: Zanichelli. ). It covered 1616 taxa of Agaricomycotina, focusing mainly on the Agaricales, Boletales, and Russulales. Several papers have also been published on aphyllophoroid fungi, updating the number of species and supplying new distributional and ecological data. Furthermore, a string of scientific papers, cited by Saitta et al. (2011 Saitta, A, Bernicchia, A, Gorjón, S P, Altobelli, E, Granito, V MLosi, C. 2011. Biodiversity of wood-decay fungi in Italy. Plant Biosyst, 145: 961-971.), together with compiled checklists of the Polyporaceae s.l. and Corticiaceae s.l., reported in Bernicchia (2005 Bernicchia, A. 2005. Polyporaceae s.l. Fungi Europaei. , 10th ed, 808Alassio, , Italy: Candusso. ) and Bernicchia and Gorjón (2010 Bernicchia, A and Gorjón, S P. 2010. Corticiaceae s.l Fungi Europaei. , 12th ed, 1008Alassio, , Italy: Candusso. ), respectively, collectively constitute an exhaustive revision of those fungi. From 1974 onwards, a remarkable number of studies on Laboulbeniales have been carried out with more than 200 taxa recorded and/or described (W. Rossi, pers. comm.). Ecological and distributional information about larger fungi is fragmented, being distributed through a huge number of papers published by a few mycologists employed in universities and a massive number of amateurs. For this reason, and taking into consideration the diversity of environments in Italy, the variety of geographical, climatic, geological, and pedological features, together with difficulties encountered in co-operation between academics and amateurs (Barron 2010 Barron, E S. 2010. The emergence and coalescence of fungal conservation 
social networks in Europe and the USA. Fungal Ecol, XXX: 1-10. ), it is currently hard to evaluate how many fungal species the country really has.

Despite those problems, Italian mycologists have been able to contribute to different Biodiversity Assessment and Strategy initiatives (Blasi et al. 2005, 2009) with a list of 4296 Basidiomycota taxa, including 3973 species, 6 subspecies, 263 varieties, and 54 forms. On the basis of the checklist of Basidiomycota, 56 of those species are endemic and 87 taxa are rare. Preliminary redlists for macrofungi at a national and regional level have also been carried out (Venturella et al. 2002 Venturella, G, Bernicchia, A, Filipello Marchisio, V, Pacioni, G, Perini, C and Onofri, S. 2002. Harmonisation of Red Lists in Europe: Some critical fungal species from Italy. Seminar on "The harmonisation of National Red Lists in Europe”, 27-28 novembre, 46-47. Leiden: the Netherlands. ; Antonini \& Antonini 2006 Antonini, D and Antonini, M. 2006. "Libro rosso dei macromiceti della Toscana". In Dal censimento alla redlist, 344Firenze: ARSIA Regione Toscana. (CDROM)). As reported in thematic contributions to the National Biodiversity Strategy in Italy (Blasi et al. 2009, 2010), the estimated number of larger fungi is currently 20,000 with at least 20 new species being described every year. Italian mycologists have also contributed to a project for mapping Important Plant Areas in Italy (the term "Important Fungus Areas" has not yet been adopted) by providing information about 42 species of macromycetes (36 with georeferenced data) and 394 georeferenced records highlighting eight important areas for fungi at a national level. Work by Italian mycologists has also resulted in Pleurotus nebrodensis (Inzenga) Quél., a critically endangered species (Venturella 2000 Venturella, G. 2000. Typification of Pleurotus nebrodensis.. Mycotaxon, 75: 229231.; Gargano et al. 2011 Gargano, M L, Saitta, A, Zervakis, G I and Venturella, G. 2011. Building the jigsaw puzzle of the critically endangered Pleurotus nebrodensis: Historical collection sites and an emended description. Mycotaxon, 115: 107-114.) being included in the IUCN Red List of Threatened Species (www.iucnredlist.org). Ongoing ex situ and in situ conservation strategies drawn up by mycologists working in the universities of Bologna, Palermo, Perugia, Siena, and Turin are devoted to target species and/or different taxonomic groups. They will be also presented in this article, together with other contributions on fungal biodiversity in Italy (Onofri et al. 2011 Onofri, S, Anastasi, A, Del Frate, G, Di Piazza, S, Garnero, NGuglielminetti, M. 2011. Biodiversity of rock, beach and water fungi in Italy. Plant Biosyst, 145: 981-990. ; Persiani et al. 2011 Persiani, A M, Tosi, S, Del Frate, G, Granito, V M, Guglielminetti, MLunghini, D. 2011. High spots for diversity of soil and litter microfungi in Italy. Plant Biosyst, 145: 972-980.; Picco et al. 2011 Picco, A M, Angelini, P, Ciccarone, C, Franceschini, A, Ragazzi, ARodolfi, M. 2011. Biodiversity of emerging pathogenic and invasive fungi in plants, animals and humans in Italy. Plant Biosyst, 145: 991-999. ; Saitta et al. 2011 Saitta, A, Bernicchia, A, Gorjón, S P, Altobelli, E, Granito, V MLosi, C. 2011. Biodiversity of wood-decay fungi in Italy. Plant Biosyst, 145: 961-971.; Varese et al. 2011 Varese, G C, Angelini, P, Bencivenga, M, Buzzini, P, Donnini, DGargano, M L. 2011. Ex-situ conservation and exploitation of fungi in Italy. Plant Biosyst, 145: 1000-1008. ).

These activities in assessing fungal diversity in Italy should be still considered as starting point and that has been a major reason for producing an updated report on the status of fungal diversity and mycological research in Italy. 


\section{Magnitude of biodiversity}

There has been a remarkable increase in knowledge of fungal diversity in Italy over the last five years. An up-to-date estimate of the number of fungi per region, including data reported in Saitta et al. (2011 Saitta, A, Bernicchia, A, Gorjón, S P, Altobelli, E, Granito, V MLosi, C. 2011. Biodiversity of wooddecay fungi in Italy. Plant Biosyst, 145: 961-971.), is provided in Figure 1 in comparison with data included by Onofri et al. (2005 Onofri, S, Bernicchia, A, Filipello Marchisio, V, Padovan, FPerini, C. 2005. Checklist dei funghi italiani - Checklist of Italian fungi, Basidiomycetes, 1-380. Sassari: C. Delfino ed.. ). Numbers from Sardinia are impressive (6500 taxa, M. Contu, pers. comm.) followed by Tuscany (3117 taxa). Over 2000 fungal taxa are reported for Emilia Romagna, Lombardy, Piedmont, Trentino-Alto Adige, and Veneto. In some Italian regions, the greatest limiting factor for documentation of fungal numbers is the lack of mycologists and/or the unavailability of records kept by amateur groups of mycologists. This is clearly evident for some regions (Figure 1) where the number of fungi has not changed from earlier estimates. Distributional and ecological information about hypogeous fungi is usually very limited in mycological studies. Detection of such fungi is usually only possible using dogs, and only a low number of semi-hypogeous fungi can be easily found by moving the superficial layer of plant litter. Distributional and ecological data on hypogeous fungi were provided in a monograph by Montecchi \& Sarasini (2000 Montecchi, A and Sarasini, M. 2000. Funghi ipogei d'Europa. Associazione Micologica Bresadola, Fondazione Centro Studi Micologici 714Vicenza), while other information is available from a number of scientific papers published by research groups working in the universities (Zambonelli \& Morara 1994 Zambonelli, A and Morara, M. 1994. Le specie di Tuberales dell'Emilia Romagna, ecologia e distribuzione. Natura e Montagna, 4: 9-32. ; Venturella \& Bencivenga 1999 Venturella, G and Bencivenga, M. 1999. Distribution and ecology of Tuber borchii in Sicily. Doc Mycol, 29: 59-61. ; Cerone et al. 2000 Cerone, G, Marino, R and Rana, G L. 2000. Studi sui funghi ipogei della Basilicata. Riv Micol, 4: 333-346. ; Ceruti et al. 2003 Ceruti, A, Fontana, A and Nosenzo, C. 2003. Le specie europee del genere Tuber, una revisione storica, 467Torino: Regione Piemonte. ; Marino et al. 2003 Marino, R, Cerone, G and Rana, G L. 2003. Studi sui funghi ipogei della Basilicata. II contributo. Rivista di Micologia. Associazione Micologica Bresadola Trento, 1: 53-62. ; Venturella et al. 2004 Venturella, G, Saitta, A, Sarasini, M, Montecchi, A and Gori, L. 2004. Contribution to the knowledge of hypogeous fungi from Sicily (SItaly). - Fl. Medit, 14: 275-284. , 2006; Saitta et al. 2008 Saitta, A, Gargano, M L, Morara, M, Ilice, $\mathrm{M}$ and Venturella, G. 2008. The hypogeous fungi from Sicily (southern Italy): New additions. Mycol Balcanica, 5: 147-152. ; Rana et al. 2010 Rana, G L, Signore, S F, Fascetti, S, Marino, R, Mang, S M and Zotta, T. 2010. Seconda segnalazione del Pachyphloeus prieguensis in Italia ed acquisizioni recenti sui funghi ipogei lucani e pugliesi. Micol Veg Medit, 25:: 47-80. ; Zotti et al. 2010b Zotti, M, Di Piazza, S, Vizzini, A, Pavarino, M and Mariotti, M G. 2010b. Hypogeous fungi in Liguria (Italy): distribution and ecology. Cryptogamie Mycologie, 31: 47-57.). The number of hypogeous fungi in Italy is currently 167 (including varieties and forms). These comprise 73 Basidiomycota, 85 Ascomycota, 3 Zygomycota, and 8 Glomeromycota. Recorded taxa belong to 55 genera and 28 families. The best represented families are Pezizaceae Dumort. (eight taxa), Tuberaceae Dumort. (five taxa), Agaricaceae Chevall. (four taxa), and Pyronemataceae Corda (four taxa). The best represented genera are Tuber P. Micheli ex F.H. Wigg. (27 taxa), Elaphomyces Nees (16 taxa), Hymenogaster Vittad. (14 taxa), Hysterangium Vittad. (eight taxa), Rhizopogon Fr. (eight taxa), Genea Vittad. (seven taxa) and Melanogaster Corda (six taxa). The current numbers of hypogeous fungi taxa by regions are reported in Figure 2. 
Figure 1. Number of fungi (Basidiomycota and Ascomycota) per region (update December 2010).

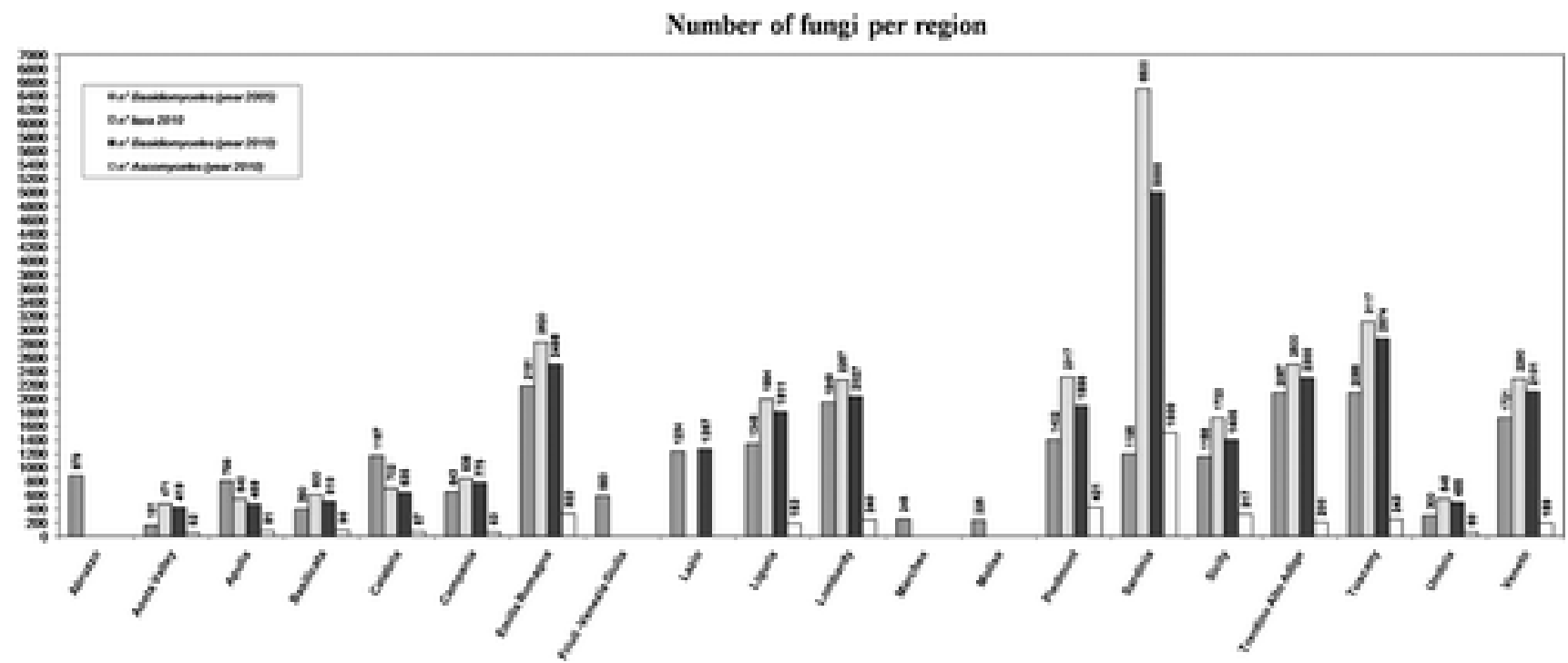

Figure 2. Number of hypogeous fungi per region and related number of Tuber species. [*Source: Montecchi \& Sarasini (2000 Montecchi, A and Sarasini, M. 2000. Funghi ipogei d'Europa. Associazione Micologica Bresadola, Fondazione Centro Studi Micologici 714Vicenza); **source: Gori (2005 Gori, L. 2005. Funghi ipogei della Lucchesia, di altre province italiane e dall'estero, 320Pacini Fazzi: Maria. ); ud = unknown data].

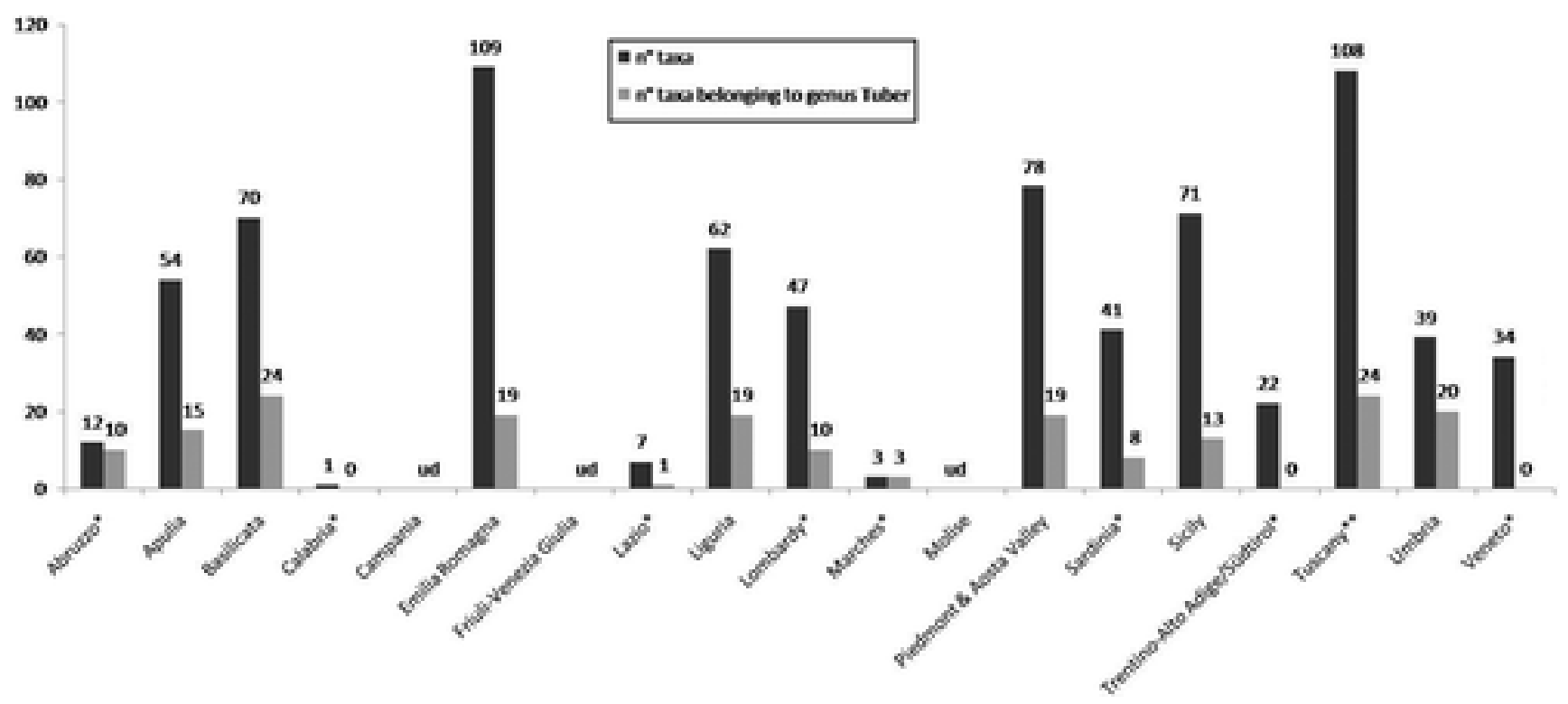

In the case of hypogeous and semi-hypogeous fungi, the term "rare" is difficult to apply but the expansion of surveyed areas in Italy over the last 10 years and an increased knowledge of their ecology and distribution permit a better evaluation of their status. In particular, Choiromyces meandriformis Vittad., Choiromyces venosus (Fr.) Th. Fr., Gauteria morchelliformis Vittad., and Picoa lefebvrei (Pat.) Maire are rare in Umbria. In Emilia Romagna several species are found only rarely. These include the ascomycetes Balsamia polysperma Vittad., Elaphomyces aculeatus Vittad., Elaphomyces anthracinus Vittad., Elaphomyces asperulus Vittad., Elaphomyces leveillei Tul. \& C. Tul., Elaphomyces maculatus Vittad., Elaphomyces morettii Vittad., Elaphomyces septatus Vittad., Fischerula macrospora Mattir., Genea hispidula Berk. ex Tul., Hydnotrya cerebriformis (Tul. \& C. Tul.) Harkn., Hydnotrya michaelis (E. Fisch.) Trappe, Leucangium carthusianum (Tul. \& C. Tul.) Paol., and Tuber monosporum (Mattir.) Vizzini. They also include the basidiomycetes Chamonixia 
caespitosa Rolland, Gautieria otthii Trog, Gautieria trabutii Chatin, Gymnomyces ellipsosporus (Zeller) Trappe, T. Lebel \& Castellano, Hymenogaster aromaticus Velen., Hymenogaster bulliardii Vittad., Hymenogaster calosporus Tul., Hymenogaster muticus Berk. \& Broome, Hymenogaster rehsteineri Bucholtz, Hymenogaster thwaitesii Berk. \& Broome, Hysterangium nephriticum Berk., Sclerogaster compactus (Tul. \& C. Tul.) Sacc., Sclerogaster hysterangioides (Tul. \& C. Tul.) Zeller \& C.W. Dodge, Stephanospora caroticolor(Berk.) Pat., and Wakefieldia macrospora (Hawker) Hawker (Montecchi \& Sarasini 2000 Montecchi, A and Sarasini, M. 2000. Funghi ipogei d'Europa. Associazione Micologica Bresadola, Fondazione Centro Studi Micologici 714Vicenza; Zambonelli \& Morara pers. comm.). In Liguria, Alpova rubescens (Vittad.) Trappe and Rhizopogon rocabrunae M.P. Martín are remarkable for their rarity (Zotti et al. 2010a Zotti, M, Di Piazza, S and Vizzini, A. 2010a. First records of Rhizopogon rocabrunae and $R$. pumilionum (Boletales) from Italy. . Mycotaxon, 113: 291-296.,b). A. rubescens, also found in the nearby region Tuscany (Gori 2005 Gori, L. 2005. Funghi ipogei della Lucchesia, di altre province italiane e dall'estero, 320Pacini Fazzi: Maria. ), is characterized by a strict symbiotic association with members of the Fagaceae (Fagus sylvatica L., Quercus sp. pl., Castanea sativa Miller). According to the molecular study by Vizzini et al. (2010 Vizzini, A, Zotti, M, Ryman, S and Ghignone, S. 2010. Typification of Octaviania rubescens (Paxillineae, Boletales) and phylogenetic hypotheses for the genus Alpova.. Mycologia, 102: 967-975.), the genus Alpova C.W. Dodge is clearly polyphyletic. Alpova olivaceotinctus (A.H. Sm.) Trappe and Alpova alexsmithii Trappe, fall within the Suillineae, whereas A. rubescens, Alpova diplophloeus (Zeller \& C.W. Dodge) Trappe \& A.H. Sm., Alpova austroalnicola L.S. Domínguez, and Alpova trappei Fogel cluster within the Paxillineae. In this suborder, A. rubescens is not related to A. diplophloeus, type of the genus Alpova (Trappe, 1975 Trappe, J M. 1975. A revision of the genus Alpova with notes on Rhizopogon and the Melanogastraceae.. Beih. Nova Hedwigia, 51: 270309. ), or to other Alpova species, and it probably represents a new and independent evolutionary line of hypogeous Paxillineae. Hypogeous fungi rare at a European level and found in Sicily include $E$. citrinus, E. maculatus, F. macrospora, Gymnomyces xanthosporus (Hawker) A.H. Sm., Melanogaster umbriniglebus Trappe \& Guzmán, Schenella simplex T. Macbr., S. pityophilus (Malençon \& Riousset) Estrada \& Lado, Sclerogaster compactus (Tul. \& C. Tul.) Sacc. and Setchelliogaster tenuipes (Setch.) Pouzar var. rheophyllus (Bertault \& Malençon) G. Moreno \& M.P. Martín (Saitta et al., 2009 Saitta, A, Gargano, M and Venturella, G. 2009. Elaphomyces citrinus and Elaphomyces maculatus in Sicily (Southern Italy). Mycotaxon, 109: 269-274.). Schenella pityophilus seems not to be rare in Salento (Apulia) or Basilicata, and in the last three years, several natural localities for S. pityophilus were found in those regions (Signore et al., 2008 Signore, S F, Rana, G L, Lolli, G and Laurita, A. 2008. Schenella pityophyla, un raro gasteromicete rinvenuto nel Salento. Micol Veget Medit, 23: 135-145. ).

The high level of diversity of these hypogeous fungi arises mainly from oak woods, followed by pine and fir woods, hazel-tree cultivation, chestnut woods, beech woods, mixed woods with a prevalence of conifers and eucalyptus reafforestations. Many hypogeous fungi grow in the Mediterranean maquis ecosystems while Genabea fragilis Tul. \& C. Tul. is usually collected under willow and poplar trees. In Mediterranean regions Descomyces albus (Berk.) Bougher \& Castellano, Hydnangium carneum Wallr., Hydnocystis clausa (Tul. \& C. Tul.) Ceruti, Hysterangium inflatum Rodway, Reddellomyces donkii (Malençon) Trappe, Castellano \& Malajczuk, S. tenuipes are frequently collected on sandy dunes and considered are strictly linked to Eucalyptus camaldulensis Dehnh., Acacia saligna (Labill.) H.L. Wendl., Pistacia lentiscus L., and Cistus sp. pl. Stephensia bombycina (Vittad.) Tul. is reported additionally from public gardens close to lime trees and from certain broad-leaved forests in the northern part of Italy where Tuber magnatum Pico is also found (Tibiletti \& Zambonelli, 1999 Tibiletti, E and Zambonelli, A. 1999. I tartufi nella provincia di Forli-Cesena, 178Bologna: Patron. , Mello et al., 2010 Mello, A, Miozzi, L, Vizzini, A, Napoli, C, Kowalchuk, G and Bonfante, P. 2010. Bacterial and fungal communities associated with Tuber magnatum-productive niches. Plant Biosyst, 144: 323-332.). Terfezia boudieri Chatin and T. claveryi Chatin, strictly linked to Helianthemum sp. 
pl., grow in Sardinia and Apulia, in environments very similar to those of Algeria, France and Morocco. Mattirolomyces terfezioides (Mattir.) E. Fisch. is associated with disturbed areas and cultivated fields with Ficus carica L. and Prunus sp. pl. or Asparagus cultivation in the sandy littoral of the Adriatic (Montecchi \& Lazzari, 1993 Montecchi, A and Lazzari, G. 1993. Atlante fotografico dei funghi ipogei, Chiavi di determinazione a cura di G. Gross. - Trento: Associazione Micologica Bresadola; Vicenza: Centro studi micologici. ). Alpova diplophloeus (Zeller \& C.W. Dodge) Trappe \& A.H. Sm. is usually collected in woods of Alnus sp. pl. (Montecchi \& Sarasini, 2000 Montecchi, A and Sarasini, M. 2000. Funghi ipogei d'Europa. Associazione Micologica Bresadola, Fondazione Centro Studi Micologici 714Vicenza). The endomycorrhizal Gigaspora lazzarii Montecchi, Ruini \& G. Gross grows in mixed grasslands directly attached to Lathyrus pratensis L. subsp. pratensis stalks.

Italy boasts a long tradition in the study, harvesting and marketing of truffles. Researchers at the universities of Turin, Bologna, Perugia and L'Aquila have maintained this tradition and more recently other research teams have been set up in the Universities of Genova, Siena, Basilicata, and Palermo. Tuber magnatum has a scattered distribution in northern and central Italy and recently new localities were found in southern Italy, but not Sicily or Sardinia. Tuber aestivum Vittad. is a very common truffle distributed in broad-leaved and conifer woods in many regions, at different altitudes and in different ecological conditions. The quality of this truffle varies so greatly, depending on environmental conditions, that for a long time it was thought there were two different species: $T$. aestivum growing mainly in south Italy and T. uncinatum Chatin in the north. Molecular tools have now, however, demonstrated that there is only a single species which for reasons of nomenclatural priority should be called T. aestivum (Paolocci et al., 2004 Paolocci, F, Rubini, A, Riccioni, C, Topini, F and Arcioni, S. 2004. Tuber aestivum and Tuber uncinatum: Two morphotypes or two species. FEMS Microbiol Lett, 235: 109-115.; Weden et al., 2005 Weden, C, Danell, E and Tibell, L. 2005. Species recognition in the truffle genus Tuber - the synonyms Tuber aestivum and Tuber uncinatum. Environ Microbiol, 7: 1535-1546.). Tuber asa-foetida Lesp. is an infrequent species mainly distributed in dry regions and linked to shrubs and herbaceous plants.

Distribution maps have been produced for truffles in some Italian regions. These include: Tuscany (Baglioni \& Gardin 1998); Emilia Romagna (Tibiletti \& Zambonelli, 1999 Tibiletti, E and Zambonelli, A. 1999. I tartufi nella provincia di Forli-Cesena, 178Bologna: Patron. ; Biagioni et al. 2005 Biagioni, V, Carletti, G, Patrizzoli, W, Marletto, V and Zambonelli, A. 2005. "La cartografia delle aree tartuficole della provincia di Modena". In G. Mondadori, editor. Appennino Modenese Terre da Tartufo. Editoriale Giorgio Mondadori 44-59. ); Abruzzo (De Laurentis \& Spinelli, 2006 De Laurentis, G and Spinelli, D. 2006. "Carta della vocazionalità tartuficola della Regione Abruzzo". 95Lanciano, $\mathrm{CH}$ : ARSSA. ); Piedmont (http://www.regione.piemonte.it/montagna/osservatorio/webgiscmcc/potenziali_tart.htm); Liguria (Pavarino et al., 2011). The scales available vary between 1:10,000 and 1:200,000. These maps are mainly based on overlay queries of data layers in a GIS environment. In particular, the map of the Ligurian pilot area is characterized by a high resolution being based on a raster grid detailed map with a spatial resolution of five metres.

Knowledge of Italian fungal diversity has also improved as a result of various specific case studies. Research has been carried out on communities of macrofungi which have been only infrequently studied in alpine habitats of Italy (Jamoni, 2008 Jamoni, P G. 2008. "Funghi alpini delle zone alpine superiori e inferiori”. In Associazione Micologica Bresadola, 544Trento: Fondazione, Centro Studi Micologici. ). Dwarfism, expressed through a reduced number of gills and smaller sporocarps, is very common in alpine macrofungi and it is not clear whether a number of alpine fungal taxa with smaller sporocarps than their forest analogues should be considered as separate species (Boertmann \& Knudsen 2006 Boertmann, D and Knudsen, H. 2006. Arctic and Alpine mycology 6. Proceedings of the Sixth International Symposium on Arcto-Alpine Mycology (ISAM 6), Greenland, 11-21 August 
2000. Danish Polar Center. - Meddr Greenland. Bioscience, 56: 161). Another interesting field of investigation is orchid mycorrhizas. Molecular methods, recently applied in several studies, have shown that mycoheterotrophic orchids have a strong mycorrhizal specificity to a narrow band of fungal taxa, such as Russula Pers., Tuber P. Micheli ex F.H. Wigg., and Hymenogaster Vittad. These, in most cases, form ectomycorrhizas with surrounding green plants (Selosse et al., 2004 Selosse, M A, Faccio, A, Scappaticci, G and Bonfante, P. 2004. Chlorophyllous and achlorophyllous specimens of Epipactis microphylla (Neottieae, Orchidaceae) are associated with ectomycorrhizal septomycetes, including truffles. Microbial Ecol, 47: 416-426.; Girlanda et al., 2006 Girlanda, M, Selosse, M A, Cafasso, D, Brilli, F, Delfine, SFabbian, R. 2006. Inefficient photosynthesis in the Mediterranean orchid Limodorum abortivum is mirrored by specific association to ectomycorrhizal Russulaceae.. Mol Ecol, 15: 491-504.). Most fungi recorded as orchid mycorrhizal symbionts belong to the anamorphic form-genus Rhizoctonia DC. which is linked to a variety of teleomorphic genera. Among these, most of the orchid-associated Rhizoctonia species belong in the families Ceratobasidiaceae, Sebacinaceae, and Tulasnellaceae (Otero et al., 2002 Otero, J T, Ackerman, J D and Bayman, P. 2002. Diversity and host specificity of endophytic Rhizoctonia-like fungi from tropical orchids. Am J Bot, 89: 1852-1858.).

Evaluation of fungal diversity does not rule out investigation of alien invasive macrofungi. These are considered to be a major cause of global biodiversity loss (Pringle \& Vellinga, 2006 Pringle, A and Vellinga, E C. 2006. Last chance to know? Using literature to explore the biogeography and invasion biology of the death cap mushroom Amanita phalloides (Vaill. ex Fr.:Fr.) Link. Biol Invasions, 8: 1131-1144.). One case study is the palaeotropical wood-inhabiting saprotroph Favolaschia calocera R. Heim (Mycenaceae). The Eighth International Mycological Congress, held in Australia, dedicated an online session to this fungus (IMC8 2006). Favolaschia calocera was found in 1999 in Multedo di Pegli (Genoa, Italy) in front of an important harbour area, and that collection was the first report of this species in Europe (Vizzini \& Zotti, 2002 Vizzini, A and Zotti, M. 2002. Favolaschia calocera, a tropical species collected in Italy. Mycotaxon, 82: 169-176.). Vizzini et al. (2009 Vizzini, A, Zotti, M and Mello, A. 2009. Alien fungal species distribution: the study case of Favolaschia calocera.. Biol Invasions, 11: 417-429.) studied, by ITS molecular analysis, the origin of the strain found in Italy and provided new insights into the distribution and the spreading strategy of this species within Italy. Favolaschia calocera was observed growing on debris of various vascular plant species (Pteridophytes, Conifers, Mono- and Dicotyledons), thus showing it to be a polyphagous. It prefers ruderal sites along transport routes and other locations subject to human disturbance. In such places, the fungus can become dominant, particularly in late summer. The abundance of $F$. calocera basidiomes in these areas suggests it may be displacing native wood-inhabiting species, and field studies on wood inhabiting macrofungi of these Italian sites have shown a very poor level of biodiversity. On the basis of field observations and phylogenetic analysis it seems likely that the first recorded occurrences of $F$. calocera in Italy probably arrived from New Zealand, via timber. Inter specimen genetic comparison mirrors a low polymorphism, as suggested by the identity of their ITS sequences. The territorial expansion of $F$. calocera is probably due to a combination of factors including its selfing life strategy and the production of antifungal compounds (strobilurins and oudemansins), as well as its ability to fill ecological niches emptied by human disturbance. Its colonizing strategy relies on wind dispersal of basidiospores.

Bertolino et al. (2004 Bertolino, S, Vizzini, A, Wauters, L A and Tosi, G. 2004. Consumption of hypogeous and epigeous fungi by the red squirrel (Sciurus vulgaris) in subalpine conifer forests. Forest Ecol Manage, 202: 227-233.) investigated the importance of macrofungi as a food resource for red squirrels (Sciurus vulgaris L. 1758) in subalpine conifer forests in the Gran Paradiso National Park (Aosta Valley) and the role of the species as a spore dispersal agent. They determined the frequency of occurrence, species diversity, and abundance of fungal spores in dung samples collected in two mixed forests of Picea excelsa (Lam.) Link and Larix decidua Miller. Spores found in spring 
all belongs to Balsamia Vittad., Elaphomyces Nees, Gautieria Vittad., Hysterangium Vittad. and Rhizopogon Fr., except in one case when spores of Boletus L. were found. In summer and autumn, spores of Boletus, Laccaria Berk. \& Broome, Balsamia, Elaphomyces, Gautieria, Hysterangium, Hydnotrya Berk. \& Broome, Hymenogaster Vittad., Leucogaster R. Hesse, Melanogaster Corda and Rhizopogon were detected. Rhizopogon was the most frequent genus consumed by squirrels (56.6\% of all dung samples), followed by Gautieria (44.4\%), Balsamia (33.3\%), and Hysterangium (25.8\%). Boletus and Laccaria were present in dung with a mean frequency of 18.5 and $8.0 \%$, respectively.

\section{In situ conservation}

Fungi are still very seldom legally protected and examples of in situ conservation remain infrequent. Courtecuisse (2001 Courtecuisse, R. 2001. Fungal Conservation. Issues and solutions, Edited by: D, Moore, MM, Nauta, SE, Evans and M, Rotheroe. 7-18. Cambridge, UK: Cambridge University Press. [CrossRef]) recognized three types of conservation strategies: a) conservation of natural habitats, b) establishment of mycological reserves, and c) use of ecological corridors. In Italy, conservation of natural habitats is determined through a project sponsored by the Italian Ministry for the Environment and Protection of the Land and Sea aimed at mapping Important Plant Areas in Italy (Blasi et al. 2009, 2010), and for protecting fungi, conservation of their habitats is the most important tool (Courtecuisse, 2001 Courtecuisse, R. 2001. Fungal Conservation. Issues and solutions, Edited by: D, Moore, MM, Nauta, SE, Evans and M, Rotheroe. 7-18. Cambridge, UK: Cambridge University Press.). A list of rare, threatened and/or endemic fungi species was recently compiled by national experts to fulfill one of the three criteria for selection of good sites: criterion A is based on the presence of species from the European Red List, lists of the Habitat Directive and the Bern Convention. Analysing information emerging from the Checklist of Italian Fungi (Basidiomycetes) and the preliminary Red Lists (Onofri et al., 2005 Onofri, S, Bernicchia, A, Filipello Marchisio, V, Padovan, FPerini, C. 2005. Checklist dei funghi italiani-Checklist of Italian fungi, Basidiomycetes, 1-380. Sassari: C. Delfino ed.. ; Venturella et al., 2002 Venturella, G, Bernicchia, A, Filipello Marchisio, V, Pacioni, G, Perini, C and Onofri, S. 2002. Harmonisation of Red Lists in Europe: Some critical fungal species from Italy. Seminar on "The harmonisation of National Red Lists in Europe", 27-28 novembre, 46-47. Leiden: the Netherlands. ) and taking into account the Bern Convention, 42 macromycetes have been chosen. Of these 26 are among the 33 species proposed for the Bern Convention appendix, while Alnicola tantilla (J. Favre) Gulden is a very rare basidiomycete growing in alpine woods of Trentino Alto Adige and Inocybe tricolor Kühner, reported from Lombardy and Veneto, is evaluated as Least Concern (LC) using the IUCN categories (D. \& M. Antonini, pers. comm). Further attempts to select important sites for fungi have been made by Leonardi et al. (2010 Leonardi, P, Salerni, E, Pecoraro, L and Perini, C. 2010. Riserve per funghi: l'esperienza toscana nel progetto IPAs (important plant areas). Micol Ital, 39:: 3-8. ), Parmasto et al. (2004), Perini \& Laganà (2003 Perini, C and Laganà, A. 2003. Towards selection of IFA (Important Fungus Areas): the Italian experience. XIV Congress of European Mycologists, 22-27 September35Yalta: Ukraine. (book of abstract)), Perini \& Salerni (2004 Perini, C and Salerni, E. 2004. Identificazione di aree particolarmente importanti per la conservazione dei funghi, $17599^{\circ}$ Congresso della Società Botanica Italiana, Torino 22-24 settembre. ), Perini et al. (in press). Fungi can increase the interest of stakeholders in protecting some areas. This was the case in a study carried out in mountain peatbogs (a habitat listed in the EU project Natura 2000) showing not only the presence of rare and threatened vascular plants and bryophytes but also of interesting macromycetes linked to sphagnum communities (Perini et al., 2002 Perini, C, Bonini, I, Romagnoli, P, Antonini, D and Antonini, M. 2002. Macrofungi and bryophytes of montane mires (Tuscany, Italy): Organisms worthy of conservation. Feddes Repertorium, 113:: 152-160. ). Similarly, in the Simbruini Mountains Natural Park, the widest protected area in Latium, three hundred and forty-seven species of fungi were recorded (Doveri et al. 2005 Doveri, F, Granito, V M and Lunghini, D. 2005. Nuovi ritrovamenti di Coprinus s.l. fimicoli in Ialia. - new findings of fimicolous Coprinus s.l. in Italy. Riv Micol, 4: 319-340. ; Granito \& Lunghini 2004 Granito, V M 
and Lunghini, D. 2004. Some Psilocybe species from Monti Simbruini Regional Natural Park, Italy. Micol Veget Medit, 19:: 115-130. , 2006, 2011; Guzman et al. 2006 Guzman, G, Granito, V M, Lunghini, D, Gandara, E and Ramirez-Guillen, F. 2006. An emendation of Psilocybe liniformans, an uncommon species found in the Central Apennines (Italy). Micol Veget Medit, 21:: 117-122. ). Particularly noteworthy was the presence of numerous grassland species of the genera Entoloma (Fr.) P. Kumm., Hygrocybe (Fr.) P. Kumm., and Camarophyllus (Fr.) P. Kumm., all considered to be indicators of grassland suitable for conservation. Another noteworthy result was the finding of Poronia punctata (L.) Fr., considered one of the rarest fungi in Europe and therefore included in the IUCN/WCMC RDL, and of two other species, Sarcosphaera coronaria (Jacq.) J. Schröt. and Phylloporus rhodoxanthus (Schwein.) Bres., both proposed for inclusion in Appendix I of the Bern Convention on the Conservation of European Wildlife and Natural Habitats. The first in situ collection of benefcial symbiotic microorganisms (arbuscular mycorrhizal fungi) in the world, located in an integrally protected area of coastal sand dunes, within the UNESCO Biosphere Reserve "Selva Pisana", in Tuscany, Italy was recently established by Turrini et al. (2008 Turrini, A, Avio, L, Bedini, $\mathrm{S}$ and Giovannetti, M. 2008. In situ collection of endangered arbuscular mycorrhizal in a Mediterranean UNESCO biosphere reserve. Biodivers Conserv, 17: 643-657.). A pilot project for implementing IUCN categories and criteria for the editing of Red Lists (Rossi et al., 2008 Rossi, G, Gentili, R, Abeli, T, Gargano, D, Foggi, BRaimondo, F M. 2008. Flora da conservare. Iniziativa per l'implementazione in Italia delle categorie e dei criteri IUCN (2001) per la redazione di nuove Liste Rosse. Inform. Bot. Ital, 40:: 7-185. , Dahlberg \& Mueller 2011 Dahlberg, A and Mueller, G M. 2011. Applying IUCN red-listing criteria for assessing and reporting on the conservation status of fungal species. Fungal Ecol, 4: 147-162.) was carried out by relevant Working Groups of the Italian Botanical Society (WG for Conservation of Nature, WG for Mycology, WG for Bryology, WG for Lichenology and WG for Floristics). Boletus dupainii Boud. and Psathyrella ammophila (Durieu \& Lév.) P. D. Orton were selected as representatives of the fungi by Perini \& Venturella (2008a Perini, C and Venturella, G. 2008a. Funghi: Boletus dupainii Boud. In: Rossi G, Gentili R, Abeli T, Gargano D, Foggi B, Raimondo FM et al., editors. Flora da conservare. Iniziativa per l'implementazione in Italia delle categorie e dei criteri IUCN (2001) per la redazione di nuove Liste Rosse. Inform Bot Ital, 40:: 7-185. ,b). Boletus dupainii is a rare symbiont of broad-leaved plants with fruiting only occasionally. The species is mainly threatened by reforestation with conifers and by silvicultural management of woods. According to IUCN criterion A, B. dupainii should be considered as Vulnerable (VU A2c) since silvicultural practices are causing 30\% reductions of natural habitat. According to criterion B the species comes out as Vulnerable [VU B2ab (ii, iii)] since the area of distribution is extremely fragmented and less than $2,000 \mathrm{~km}^{2}$. The regional status of $B$. dupainii is Not Evaluated (NE) at the national level and Endangered (EN) in Tuscany. Conservation strategies for this fungus are mainly oriented towards protection of its habitat included in parks and nature reserves. Psathyrella ammophila, included in Red Lists of the Czech Republic, Germany, Hungary, Latvia, Norway, Poland and Sweden, is a common species in Italy growing in sandy coastal areas. Heavy pressure from human use of coastal sandy dune environments has resulted in $P$. ammophila being rated as Near threatened (NT) (A2c) on the basis of criterion A and Vulnerable [VU B2ab (iii)] because of suspected reduction of population size and an estimated $15 \%$ progressive reduction of habitat. In situ conservation strategies for this fungus are similar to those for $B$. dupainii. In the IUCN Red List of Threatened Species, Pleurotus nebrodensis (Inzenga) Quél., is listed as CR (Critically Endangered) because the area where it is found is less than 100 kmô, the population is severely fragmented, and there is a decline in the number of localities and mature individuals. This mushroom only occurs in northern Sicily, growing in scattered localities in the Madonie mountains from 1200 to $2000 \mathrm{~m}$ in altitude. It is estimated that fewer than 250 individuals reach maturity each year and the population is decreasing (Gargano et al., 2011 Gargano, M L, Saitta, A, Zervakis, G I and Venturella, G. 2011. Building the jigsaw puzzle of the critically endangered Pleurotus nebrodensis: Historical collection sites and an emended description. Mycotaxon, 115: 107-114.). Pleurotus nebrodensis grows on limestone substrates, in pastures containing Cachrys ferulacea (L.) Calestani, a member of 
the Apiaceae or celery family. The population declines are due to the increasing number of mushroom gatherers, both professional and amateur, who are encouraged by the high price this mushroom commands. In addition to this increased human pressure on the remaining natural populations, unripe fungi are usually collected. The conservation action for this fungus is legally binding since the Madonie Park administration has issued rules controlling mushroom collecting within the Park. In particular, collection of $P$. nebrodensis is totally forbidden in zone A of the Park which is an integral reserve area. In other zones the collection of unripe mushrooms (i.e., basidiomata less than $3 \mathrm{~cm}$ in diameter) is forbidden. Other in situ conservation action involves inoculation of roots of the associated plant $C$. ferulacea with grain mycelia of $P$. nebrodensis in the hope of increasing mushroom fructification in the wild.

\section{Acknowledgements}

The authors would like to thank Dr. David Minter (UK) for his help with linguistic revision and E. Roca, M. Contu, D. Antonini, M. Antonini and D. Puntillo for providing regional data.

\section{References}

- Antonini, D and Antonini, M. 2006. "Libro rosso dei macromiceti della Toscana". In Dal censimento alla redlist, 344Firenze: ARSIA Regione Toscana. (CDROM)

- Baglioni, F and Gardin, L. 1998. "Carta della vocazione naturale del territorio toscano alla produzione di tartufo scorzone". In I Tartufi in Toscana, Edited by: Mazzei. 167-170. Firenze: ARSIA, Regione Toscana.

- Barron, E S. 2010. The emergence and coalescence of fungal conservation social networks in Europe and the USA. Fungal Ecol, XXX: 1-10.

- Bernicchia, A. 2005. Polyporaceae s.I. Fungi Europaei. , 10th ed, 808Alassio, , Italy: Candusso.

- Bernicchia, A and Gorjón, S P. 2010. Corticiaceae s.I Fungi Europaei. , 12th ed, 1008Alassio, , Italy: Candusso.

- Bertolino, S, Vizzini, A, Wauters, L A and Tosi, G. 2004. Consumption of hypogeous and epigeous fungi by the red squirrel (Sciurus vulgaris) in subalpine conifer forests. Forest Ecol Manage, 202: 227-233.

- Biagioni, V, Carletti, G, Patrizzoli, W, Marletto, V and Zambonelli, A. 2005. "La cartografia delle aree tartuficole della provincia di Modena". In G. Mondadori, editor. Appennino Modenese Terre da Tartufo. Editoriale Giorgio Mondadori 44-59.

- Boitani, L, La Posta, S, Manes, F and Marchetti, M. 2005. "Stato della biodiversità in Italia". In Contributo alla strategia nazionale per la biodiversità, Edited by: Blasi, C. 446Roma: Palombi.

- Blasi C, Marignani M, Copiz R, Fipaldini M. editors. 2009. A thematic contribution to the National Biodiversity Strategy. Mapping the Important Plant Areas in Italy. Rome: Palombi \& Partner s.r.l. p. 31

- Blasi, C, Marignani, M, Copiz, R, Fipaldini, M and Del Vico, E. 2010. Le aree importanti per le piante nelle regioni d'Italia: il presente e il futuro della conservazione del nostro patrimonio botanico, 224Roma: Progetto Artiser.

- Boccardo, F, Traverso, M, Vizzini, A and Zotti, M. 2008. Funghi d'Italia, 623Bologna: Zanichelli.

- Boertmann, D and Knudsen, H. 2006. Arctic and Alpine mycology 6. Proceedings of the Sixth International Symposium on Arcto-Alpine Mycology (ISAM 6), Greenland, 11-21 August 2000. Danish Polar Center. - Meddr Greenland. Bioscience, 56: 161 
- Cerone, G, Marino, R and Rana, G L. 2000. Studi sui funghi ipogei della Basilicata. Riv Micol, 4: 333-346.

- Ceruti, A, Fontana, A and Nosenzo, C. 2003. Le specie europee del genere Tuber, una revisione storica, 467Torino: Regione Piemonte.

- Courtecuisse, R. 2001. Fungal Conservation. Issues and solutions, Edited by: D, Moore, MM, Nauta, SE, Evans and M, Rotheroe. 7-18. Cambridge, UK: Cambridge University Press.

- Dahlberg, A and Mueller, G M. 2011. Applying IUCN red-listing criteria for assessing and reporting on the conservation status of fungal species. Fungal Ecol, 4: 147-162.

- De Laurentis, G and Spinelli, D. 2006. "Carta della vocazionalità tartuficola della Regione Abruzzo". 95Lanciano, $\mathrm{CH}$ : ARSSA.

- Doveri, F, Granito, V M and Lunghini, D. 2005. Nuovi ritrovamenti di Coprinus s.l. fimicoli in lalia. - new findings of fimicolous Coprinus s.I. in Italy. Riv Micol, 4: 319-340.

- Gargano, M L, Saitta, A, Zervakis, G I and Venturella, G. 2011. Building the jigsaw puzzle of the critically endangered Pleurotus nebrodensis: Historical collection sites and an emended description. Mycotaxon, 115: 107-114.

- Girlanda, M, Selosse, M A, Cafasso, D, Brilli, F, Delfine, SFabbian, R. 2006. Inefficient photosynthesis in the Mediterranean orchid Limodorum abortivum is mirrored by specific association to ectomycorrhizal Russulaceae.. Mol Ecol, 15: 491-504.

- Gori, L. 2005. Funghi ipogei della Lucchesia, di altre province italiane e dall'estero, 320Pacini Fazzi: Maria.

- Granito, V M and Lunghini, D. 2004. Some Psilocybe species from Monti Simbruini Regional Natural Park, Italy. Micol Veget Medit, 19:: 115-130.

- Granito, V M and Lunghini, D. 2006. Updated observations on Poronia punctata. Micol Veget Medit, 21:: 71-76.

- Granito, V M and Lunghini, D. 2011. Biodiversity of macrofungi in the beech forests and calcareous grasslands of the Simbruini Mountains Regional Park (central Apennines, Italy). Plant Biosyst, 145: 381-396.

- Guzman, G, Granito, V M, Lunghini, D, Gandara, E and Ramirez-Guillen, F. 2006. An emendation of Psilocybe liniformans, an uncommon species found in the Central Apennines (Italy). Micol Veget Medit, 21:: 117-122.

- IMC8. 2006. "International Mycological Congress, Cairns, Australia - Fungus of the month July 2005, Favolaschia calocera". Available: http://www. rbg.vic.gov.au/research_and_conservation/fungi. Accessed Nov 20113

- Jamoni, P G. 2008. "Funghi alpini delle zone alpine superiori e inferiori". In Associazione Micologica Bresadola, 544Trento: Fondazione, Centro Studi Micologici.

- Leonardi, P, Salerni, E, Pecoraro, L and Perini, C. 2010. Riserve per funghi: I'esperienza toscana nel progetto IPAs (important plant areas). Micol Ital, 39:: 3-8.

- Marino, R, Cerone, G and Rana, G L. 2003. Studi sui funghi ipogei della Basilicata. II contributo. Rivista di Micologia. Associazione Micologica Bresadola Trento, 1: 53-62.

- Mello, A, Miozzi, L, Vizzini, A, Napoli, C, Kowalchuk, G and Bonfante, P. 2010. Bacterial and fungal communities associated with Tuber magnatum-productive niches. Plant Biosyst, 144: 323-332. 
- Montecchi, A and Lazzari, G. 1993. Atlante fotografico dei funghi ipogei, Chiavi di determinazione a cura di G. Gross. - Trento: Associazione Micologica Bresadola; Vicenza: Centro studi micologici.

- Montecchi, A and Sarasini, M. 2000. Funghi ipogei d'Europa. Associazione Micologica Bresadola, Fondazione Centro Studi Micologici 714Vicenza

- Onofri, S, Bernicchia, A, Filipello Marchisio, V, Padovan, FPerini, C. 2005. Checklist dei funghi italiani - Checklist of Italian fungi, Basidiomycetes, 1-380. Sassari: C. Delfino ed..

- Onofri, S, Anastasi, A, Del Frate, G, Di Piazza, S, Garnero, NGuglielminetti, M. 2011. Biodiversity of rock, beach and water fungi in Italy. Plant Biosyst, 145: 981-990.

- Otero, J T, Ackerman, J D and Bayman, P. 2002. Diversity and host specificity of endophytic Rhizoctonialike fungi from tropical orchids. Am J Bot, 89: 1852-1858.

- Paolocci, F, Rubini, A, Riccioni, C, Topini, F and Arcioni, S. 2004. Tuber aestivum and Tuber uncinatum: Two morphotypes or two species. FEMS Microbiol Lett, 235: 109-115.

- Parmasto E, Perini C, Rahko T. 2004. Attempts to introduce fungi in nature conservation activities. Fourth European Conference on the Conservation of Wild Plants, Valencia 17-20 September. p. 7 (book of abstract)

- Pavarino, M, Rellini, I, Bozzano, M, Mariotti, M G and Zotti, M. 2008. "Indicator-based approach for mapping and assessing Tuber magnatum Pico presence in Western Liguria (Italy)". In Atti del $3^{\circ}$ Convegno Internazionale sul Tartufo 273-281Spoleto

- Perini, C, Bonini, I, Romagnoli, P, Antonini, D and Antonini, M. 2002. Macrofungi and bryophytes of montane mires (Tuscany, Italy): Organisms worthy of conservation. Feddes Repertorium, 113:: 152-160.

- Perini, C and Laganà, A. 2003. Towards selection of IFA (Important Fungus Areas): the Italian experience. XIV Congress of European Mycologists, 22-27 September35Yalta: Ukraine. (book of abstract)

- Perini, C, Leonardi, P, Pecoraro, L and Salerni, E. in press. The important plant areas program from a mycological point of view: The regional experience in an European context. Fitosociologia, 48. suppl. 1.

- Perini, C and Salerni, E. 2004. Identificazione di aree particolarmente importanti per la conservazione dei funghi, $17599^{\circ}$ Congresso della Società Botanica Italiana, Torino 22-24 settembre.

- Perini, C and Venturella, G. 2008a. Funghi: Boletus dupainii Boud. In: Rossi G, Gentili R, Abeli T, Gargano D, Foggi B, Raimondo FM et al., editors. Flora da conservare. Iniziativa per l'implementazione in Italia delle categorie e dei criteri IUCN (2001) per la redazione di nuove Liste Rosse. Inform Bot Ital, 40:: 7-185.

- Perini, C and Venturella, G. 2008b. Funghi: Psathyrella ammophila (Durieu et Lév.) P.D. Orton. pp. 151152. In: Rossi G, Gentili R, Abeli T, Gargano D, Foggi B, Raimondo FM, editors. Flora da conservare. Iniziativa per l'implementazione in Italia delle categorie e dei criteri IUCN (2001) per la redazione di nuove Liste Rosse. Inform Bot Ital, 40:: 7-185.

- Persiani, A M, Tosi, S, Del Frate, G, Granito, V M, Guglielminetti, MLunghini, D. 2011. High spots for diversity of soil and litter microfungi in Italy. Plant Biosyst, 145: 972-980.

- Picco, A M, Angelini, P, Ciccarone, C, Franceschini, A, Ragazzi, ARodolfi, M. 2011. Biodiversity of emerging pathogenic and invasive fungi in plants, animals and humans in Italy. Plant Biosyst, 145: 991-999.

- Pringle, A and Vellinga, E C. 2006. Last chance to know? Using literature to explore the biogeography and invasion biology of the death cap mushroom Amanita phalloides (Vaill. ex Fr.:Fr.) Link. Biol Invasions, 8: 11311144. 
- Rana, G L, Signore, S F, Fascetti, S, Marino, R, Mang, S M and Zotta, T. 2010. Seconda segnalazione del Pachyphloeus prieguensis in Italia ed acquisizioni recenti sui funghi ipogei lucani e pugliesi. Micol Veg Medit, 25:: 47-80.

- Rossi, G, Gentili, R, Abeli, T, Gargano, D, Foggi, BRaimondo, F M. 2008. Flora da conservare. Iniziativa per I'implementazione in Italia delle categorie e dei criteri IUCN (2001) per la redazione di nuove Liste Rosse. Inform. Bot. Ital, 40:: 7-185.

- Saitta, A, Gargano, M L, Morara, M, llice, M and Venturella, G. 2008. The hypogeous fungi from Sicily (southern Italy): New additions. Mycol Balcanica, 5: 147-152.

- Saitta, A, Gargano, M and Venturella, G. 2009. Elaphomyces citrinus and Elaphomyces maculatus in Sicily (Southern Italy). Mycotaxon, 109: 269-274.

- Saitta, A, Bernicchia, A, Gorjón, S P, Altobelli, E, Granito, V MLosi, C. 2011. Biodiversity of wood-decay fungi in Italy. Plant Biosyst, 145: 961-971.

- Selosse, M A, Faccio, A, Scappaticci, G and Bonfante, P. 2004. Chlorophyllous and achlorophyllous specimens of Epipactis microphylla (Neottieae, Orchidaceae) are associated with ectomycorrhizal septomycetes, including truffles. Microbial Ecol, 47: 416-426.

- Signore, S F, Rana, G L, Lolli, G and Laurita, A. 2008. Schenella pityophyla, un raro gasteromicete rinvenuto nel Salento. Micol Veget Medit, 23: 135-145.

- Tibiletti, E and Zambonelli, A. 1999. I tartufi nella provincia di Forlì-Cesena, 178Bologna: Patron.

- Tkalčec, Z, Mešić, A and Antonić, O. 2005. Survey of the gasteral Basidiomycota (fungi) of Croatia. Nat Croat, 14: 99-120.

- Trappe, J M. 1975. A revision of the genus Alpova with notes on Rhizopogon and the Melanogastraceae.. Beih. Nova Hedwigia, 51: 270-309.

- Turrini, A, Avio, L, Bedini, S and Giovannetti, M. 2008. In situ collection of endangered arbuscular mycorrhizal in a Mediterranean UNESCO biosphere reserve. Biodivers Conserv, 17: 643-657.

- Varese, G C, Angelini, P, Bencivenga, M, Buzzini, P, Donnini, DGargano, M L. 2011. Ex-situ conservation and exploitation of fungi in Italy. Plant Biosyst, 145: 1000-1008.

- Venturella, G. 2000. Typification of Pleurotus nebrodensis.. Mycotaxon, 75: 229-231.

- Venturella, G and Bencivenga, M. 1999. Distribution and ecology of Tuber borchii in Sicily. Doc Mycol, 29: 59-61.

- Venturella, G, Bernicchia, A, Filipello Marchisio, V, Pacioni, G, Perini, C and Onofri, S. 2002. Harmonisation of Red Lists in Europe: Some critical fungal species from Italy. Seminar on "The harmonisation of National Red Lists in Europe", 27-28 novembre, 46-47. Leiden: the Netherlands.

- Venturella, G, Saitta, A, Sarasini, M, Montecchi, A and Gori, L. 2004. Contribution to the knowledge of hypogeous fungi from Sicily (S-Italy). - Fl. Medit, 14: 275-284.

- Venturella, G, Pecorella, E, Saitta, A, Zambonelli, A and Morara, M. 2006. Ecology and distribution of hypogeous fungi from Sicily (southern Italy). Cryptogamie, Mycologie, 27: 201-217.

- Vizzini, A and Zotti, M. 2002. Favolaschia calocera, a tropical species collected in Italy. Mycotaxon, 82: 169176. 
- Vizzini, A, Zotti, M and Mello, A. 2009. Alien fungal species distribution: the study case of Favolaschia calocera.. Biol Invasions, 11: 417-429.

- Vizzini, A, Zotti, M, Ryman, S and Ghignone, S. 2010. Typification of Octaviania rubescens (Paxillineae, Boletales) and phylogenetic hypotheses for the genus Alpova.. Mycologia, 102: 967-975.

- Weden, C, Danell, E and Tibell, L. 2005. Species recognition in the truffle genus Tuber - the synonyms Tuber aestivum and Tuber uncinatum. Environ Microbiol, 7: 1535-1546.

- Zambonelli, A and Morara, M. 1994. Le specie di Tuberales dell'Emilia Romagna, ecologia e distribuzione. Natura e Montagna, 4: 9-32.

- Zotti, M, Di Piazza, S and Vizzini, A. 2010a. First records of Rhizopogon rocabrunae and R. pumilionum (Boletales) from Italy. . Mycotaxon, 113: 291-296.

- Zotti, M, Di Piazza, S, Vizzini, A, Pavarino, M and Mariotti, M G. 2010b. Hypogeous fungi in Liguria (Italy): distribution and ecology. Cryptogamie Mycologie, 31: 47-57. 